\title{
KUALITAS BATA BETON BERLUBANG DENGAN BAHAN LIMBAH TAILING PENAMBANGAN EMAS UPBE PONGKOR
}

\author{
Amalia $^{1}$ dan Agus Murdiyoto ${ }^{2}$ \\ 1,2 Jurusan Teknik Sipil, Politeknik Negeri Jakarta, Jl. Prof. Dr. GA. Siwabessy Kampus UI, Depok 16424 \\ Email: ${ }^{1}$ amaliaiva@yahoo.com
}

\begin{abstract}
This study aims to investigate the potential of gold mining tailings UPBE Pongkor as hollow concrete brick making material and investigate its properties. The study was conducted by making hollow concrete brick composition 1 PC: 8 aggregate, consisting of 4 variations of tailings as aggregate substitution, ie $0 \%, 25 \%, 50 \%$, and $75 \%$ of the aggregate weight. The results showed that (1) the use of tailings as aggregate replacement in concrete hollow brick can reduce the compressive strength of concrete blocks, (2) can be used as a substitute Tailings aggregate up to 75\%, wherein the composition produces hollow concrete bricks that still meets ISO standards for class IV concrete brick that can be used as non-structural partition wall, (3) the higher levels replace sand tailings, water absorption in hollow concrete brick is also higher, (4) weight content of concrete hollow brick using more and more tailings, bulk density is decreased.
\end{abstract}

Key words : Hollow concrete brick, compressive strength, tailing of gold mining

\section{PENDAHULUAN}

Tailing merupakan limbah proses penghancuran batuan yang diendapkan untuk memisahkan bijih dari emas. Limbah tailing emas yang dibuang masih mengandung logam-logam berat yang berbahaya bagi lingkungan. Pada proses penambangan emas, tailing merupakan limbah yang jumlahnya sangat besar, karena dari penambangan yang dilakukan, hanya kurang dari $3 \%$ yang menghasilkan emas, sisanya berupa limbah tailing. PT Antam UPBE pongkor merupakan salah satu perusahaan penambangan emas yang menghasilkan tailing \pm 350.000 ton per tahun. Limbah tailing ini memerlukan penanganan dan pengelolaan khusus terutama area yang luas dan steril sebagai tempat penampungan (tailing dam) agar tidak mencemari lingkungan. Sampai saat ini, tailing di daerah pongkor baru dimanfaatkan $\pm 60 \%$ dari total volume sebagai bahan timbunan bekas galian yang sudah ditambang. Sisa tailing 40\% ditampung pada tailing dam dan belum dimanfaatkan secara maksimal.

Secara fisik, tailing merupakan batuan berbentuk pasir halus sampai sedang dengan komposisi bahan $\pm 75 \%$ kuarsa, $23 \%$ oksida besi dan 2\% mineral lain. Penelitian penggunaan tailing sebagai bahan perkerasan jalan menyebutkan bahwa tailing yang dimanfaatkan sebagai campuran perkerasan jalan sampai $40 \%$ dapat memperbaiki sifat tanah dasar jalan (Saing. 2008). Selain digunakan sebagai perkerasan jalan, tailing juga dapat digunakan sebagai bahan bata cetak yang menghasilkan bata kelas 25 dan 50 (Widodo et.al. 2010). Penelitian lain yang menggunakan tailing sebagai bahan pengisi pada beton untuk lingkungan laut menghasilkan beton yang lebih tahan di lingkungan laut dibandingkan beton tanpa tailing (Syah \& Saputra.2011).

Dari beberapa hasil penelitian tersebut, ada beberapa hal yang masih perlu dikembangkan lebih lanjut, yaitu 
pemanfaatan tailing sebagai bahan baku pembuatan dinding bata beton berlubang. Penelitian bertujuan untuk meneliti kualitas bata beton berlubang yang menggunakan tailing limbah penambangan emas sebagai bahan pengisi dan mencari prosentase optimum tailing sebagai bahan pengisi pada bata beton berlubang yang menghasilkan karakteristik bata beton sesuai dengan SNI 03-0348-1989.

\section{Bahan-Bahan yang Mempengaruhi Kualitas Bata Beton}

Bahan penyusun bata beton terdiri dari bahan perekat, agregat, dan air dengan atau tanpa bahan tambah. Perbandingan antara bahan perekat dan bahan pengisi tergantung dari spesifikasi bata beton yang diinginkan, kekuatan bata beton yang diinginkan serta tujuan dari penggunaan bata beton tersebut. Kekuatan dan sifat bata beton sangat dipengaruhi oleh jumlah dan jenis perekat yang digunakan, sifat agregat, jumlah air yang digunakan serta bahan tambah.

\section{Bahan Perekat}

Bahan perekat yang biasa digunakan adalah bahan perekat hidrolis seperti kapur padam, puzolan, semen portland atau kombinasi dari bahan-bahan tersebut. Pemilihan jenis bahan perekat tergantung dari beberapa hal, yaitu: jenis bahan bangunan yang direkatkan, kekuatan yang ingin dicapai, iklim dan cuaca dimana bangunan ditempatkan, hasil akhir tampilan dinding yang diinginkan, dan persyaratan mutu sesuai standar.

Semen Portland sebagai bahan perekat pada bata beton menghasilkan kuat tekan yang lebih tinggi dibandingkan dengan kapur. Selain itu jumlah semen dalam bata beton juga sangat mempengaruhi kekuatan semen. Hal ini sesuai dengan hasil penelitian Subari dan Rahman (2008) yang menyebutkan bahwa semakin tinggi jumlah semen yang ditambahkan pada bata beton maka kuat tekannya semakin meningkat. Hasil penelitian Taufik dan Setiadji (2008) juga menyebutkan bahwa semakin banyak jumlah semen maka kuat tekan bata beton dengan agregat limbah Drilling Cutting semakin meningkat.

\section{Bahan Pengisi}

Selain perekat, sifat-sifat agregat sebagai bahan pengisi juga sangat mempengaruhi sifat dan kekuatan bata beton. Sifat-sifat agregat yang mempengaruhi mutu bata beton adalah: susunan butiran (gradasi agregat), berat jenis, kadar zat organic dan kekasaran permukaan agregat. Agregat yang digunakan sebagai bahan pengisi bata beton harus memenuhi persyaratan, yaitu:

- Butir maksimal $10 \mathrm{~mm}$ untuk bata beton berlubang dan 2/3 tebal dinding tertipis untuk bata berlubang.

- Angka kehalusan butiran agregat 3,45 - 3,70 maksimum 4,25.

- Susunan butir agregat memenuhi persyaratan seperti pada Tabel 1.

Tabel 1. Susunan Butir (Gradasi)

\begin{tabular}{cccc} 
& \multicolumn{3}{c}{ Agregat Untuk Bata Beton } \\
\hline & & $\begin{array}{c}\text { Agregat } \\
\text { alam }\end{array}$ & $\begin{array}{c}\text { Agregat } \\
\text { buatan }\end{array}$ \\
\hline $\begin{array}{c}\text { Tertahan } \\
\text { di }\end{array}$ & $12,5 \mathrm{~mm}$ & Nihil & Nihil \\
& 10 & $0-5 \%$ & $0-5 \%$ \\
& 4,8 & $20-30 \%$ & $16-28 \%$ \\
& 2,4 & $10-23 \%$ & $21-29 \%$ \\
& 1,2 & $10-20 \%$ & $16-24 \%$ \\
& 0,6 & $10-20 \%$ & $11-19 \%$ \\
& 0,3 & $10-20 \%$ & $6-14 \%$ \\
Lolos & 0,15 & $5-15 \%$ & $3-9 \%$ \\
& 0,15 & $1,5-10 \%$ & $3-9 \%$ \\
\hline
\end{tabular}

- Agregat harus keras, yang ditunjukkan dengan kandungan silika dalam jumlah besar.

- Agregat harus bersih tidak mengandung butiran halus $(<$ 0,075mm), dibatasi maksimum 3\%. Butiran halus yang jumlahnya terlalu banyak akan menyebabkan 
penyusutan yang besar pada bata beton.

- Bersih dari zat organic, agar tidak mengganggu rekatan dengan bahan perekat.

Agregat yang memiliki gradasi yang baik dan berat jenis yang tinggi, akan menghasilkan bata beton dengan kuat tekan yang tinggi pula. Hal ini sesuai dengan hasil penelitian Sugiarto (2011) yang menyebutkan bahwa bata beton dengan kuat tekan tertinggi dihasilkan dari agregat $40 \%$ bottom ash yang mempunyai berat jenis tinggi dan gradasi baik sesuai dengan standar. Agregat dengan berat jenis rendah dapat menurunkan kuat tekan bata beton. Hal ini sesuai dengan hasil penelitian Suhardjo dan Basuki (2009) yang menyebutkan bahwa penggunaan agregat perlit dengan berat jenis rendah (ringan), pada penambahan di atas $12 \%$ justru menurunkan kuat tekan bata beton.

Agregat yang didominasi oleh butiran halus justru akan menurunkan kuat tekan bata beton. Hal ini sejalan dengan hasil penelitian Taufik dan Setiadji (2008) yang menyebutkan bahwa semakin banyak penggunaan agregat limbah drilling cutting yang memiliki butiran halus, kuat tekan bata beton semakin menurun. Kekerasan dan kekasaran permukaan agregat juga berpengaruh terhadap ikatan semen dengan agregat pada bata beton. Hal ini sesuai dengan hasil penelitian Laksono (2009) yang menyebutkan bahwa bata beton dengan agregat limbah plastik yang mempunyai permukaan licin ternyata mempunyai penyerapan air yang lebih besar dan kuat tekan yang lebih rendah dibandingkan dengan bata beton dengan agregat alam.

\section{Sifat-Sifat Bata Beton}

Bata beton adalah suatu jenis unsur bangunan berbentuk bata yang terbuat dari campuran bahan perekat, agregat dan air dengan atau tanpa bahan tambah yang dicampur sedemikian rupa sehingga mudah dicetak. Bata beton terdiri dari dua jenis, yaitu bata beton berlubang dan bata beton berlobang. Bata beton berlubang merupakan bata beton yang memiliki penampang pejal $75 \%$ atau lebih dari luas penampang seluruhnya, dan memiliki volume pejal lebih dari $75 \%$ volume seluruhnya. Bata beton berlobang merupakan bata beton yang memiliki luas penampang lubang lebih dari $25 \%$ dari volume bata seluruhnya. Bata Beton Berlubang adalah bata yang pada permukaannya terdapat lubang-lubang, dan jumlah luas lubang itu 15\%-35\% luas penampang batanya.

Penggunaan bata beton untuk pasangan dinding lebih menguntungkan dibandingkan dengan bata cetak biasa. Adapun keuntungannya adalah: lebih menghemat pemakaian adukan dibandingkan pasangan batu bata biasa, dinding tidak perlu diplester, pemasangan dinding lebih cepat, dan dapat menghemat penggunaan air dan semen dalam proses membangun.

Sifat penting bata beton untuk menghasilkan pasangan dinding yang baik antara lain: mempunyai ukuran seragam, tidak terdapat retak-retak dan cacat terutama pada sudut siku satu terhadap yang lain dan sudut rusuknya tidak boleh mudah diserpihkan dengan kekuatan jari tangan, memiliki kekuatan rekatan yang cukup baik, mempunyai kekuatan yang cukup untuk menahan beban, stabil/tidak banyak berubah volumenya, tahan lama dan memberikan penampakan yang baik. Apabila syarat-syarat bahan dan cara pengerjaannya dipenuhi, biasanya hasilnya akan memuaskan. 
Adapun sifat-sifat bata beton yang perlu diperhatikan adalah :

a. Keseragaman ukuran. Untuk menghasilkan pasangan dinding yang baik, bata beton harus mempunyai ukuran yang seragam.

b. Penyerapan air. Bata beton harus mempunyai penyerapan air yang memenuhi persyaratan, yaitu maksimum $35 \%$ untuk mutu B70 dan $25 \%$ untuk mutu B100. Bata beton yang penyerapan airnya terlalu besar menyebabkan dinding lembab dan mudah rusak. Penyerapan air berhubungan erat dengan mutu agregat yang digunakan. Agregat dengan permukaan kasar akan memberikan ikatan yang baik dengan semen sehingga bata beton lebih padat. Hal ini sesuai dengan hasil penelitian Laksono (2009) yang menyebutkan bahwa bata beton dengan agregat limbah plastik yang mempunyai permukaan licin ternyata mempunyai penyerapan air yang lebih besar dibandingkan dengan bata beton dengan agregat alam.

c. Kuat tekan bata beton. Kekuatan pada bata beton/bata beton dipengaruhi oleh mutu agregat, mutu perekat dan perbandingan campuranya.

Adapun kuat tekan bata beton menurut SNI 03-0349-1989 disajikan pada Tabel 2.

Tabel 2. Kuat Tekan dan Penyerapan Air Bata Beton Berlubang Menurut SNI 03-0349-1989

\begin{tabular}{|c|c|c|c|c|}
\hline & \multicolumn{4}{|c|}{ Tingkat mutu bata beton berlubang } \\
\hline Sifat Fisik & I & II & III & IV \\
\hline $\begin{array}{l}\text { Kuat tekan bruto rata-rata } \\
\left(\mathrm{kg} / \mathrm{cm}^{2}\right)\end{array}$ & 70 & 50 & 35 & 20 \\
\hline $\begin{array}{l}\text { Kuat tekan bruto masing-masing } \\
\text { benda uji }\left(\mathrm{kg} / \mathrm{cm}^{2}\right)\end{array}$ & 65 & 35 & 21 & 17 \\
\hline Penyerapan Air rata-rata & 25 & 35 & $\cdot$ & $\cdot$ \\
\hline
\end{tabular}

\section{Limbah Tailing Penambangan Emas}

Tailing merupakan limbah proses penghancuran batuan yang diendapkan untuk memisahkan bijih dari emas. Limbah tailing emas yang dibuang masih mengandung logam-logam berat yang berbahaya bagi lingkungan. Pada proses penambangan emas, tailing merupakan limbah yang jumlahnya sangat besar, karena dari penambangan yang dilakukan, hanya kurang dari $3 \%$ yang menghasilkan emas, sisanya berupa limbah tailing. Secara fisik, tailing merupakan batuan berbentuk pasir halus sampai sedang dengan komposisi bahan \pm 75\% kuarsa, $23 \%$ oksida besi dan 2\% mineral lain. Tailing sebagai limbah penghancuran batuan masih mengandung mineral-mineral seperti tercantum pada Tabel 3.

Tabel 3. Komposisi Mineral Tailing Pengolahan Emas (Widodo et al. 2010)

\begin{tabular}{clc}
\hline $\mathrm{N}_{0}$ & \multicolumn{1}{c}{ Jenis Mineral } & Prosentase (\%) \\
\hline 1 & Kuarsa (Si02) & 54 \\
2 & Dolomit (CaMg) & 2,5 \\
3 & Kalsit (CaCO3) & 7 \\
4 & Anhidrit (CaSO4) & 2 \\
5 & Clay/KaolinMonmorilonit/llite & 9 \\
6 & Oksida Besi (Fe0) & 3 \\
\hline
\end{tabular}

Selain mengandung mineral-mineral seperti Tabel 2.3, tailing juga mengandung logam-logam berat yang dapat mencemari lingkungan. Pemanfaatan tailing harus memperhatikan kandungan logamlogam berat ini, sehingga pemanfaatannya tidak membahayakan lingkungan. Hasil penelitian terhadap tailing penambangan emas UPBE Pongkor menyebutkan bahwa tailing ini mengandung unsur logam $\mathrm{Mn} \mathrm{0,86}$ $\mathrm{mg} / \mathrm{L}$, Fe 0,366 mg/L, Pb 0,035 mg/L, Cd 0,027mg/L, Zn 0,033 mg/L dan $\mathrm{Cu}$ 0,22 mg/L. Nilai ini berada di bawah nilai baku mutu sehingga tailing aman digunakan (Prasetyo. 2011). 


\section{METODE PENELITIAN}

\section{Variasi dan Jenis Benda Uji}

Penelitian dilakukan dengan cara membuat benda uji bata beton berlubang ukuran $34 \mathrm{~cm} \times 15 \mathrm{~cm} \times$ $8,5 \mathrm{~cm}$. Benda uji dibuat dengan 4 variasi kadar limbah tailing pengganti pasir alam yaitu : $0 \%, 25 \%, 50 \%$, dan $75 \%$. Bata beton dibuat dengan komposisi campuran 1 Pc : 8 agregat. Untuk meneliti perkembangan kuat tekan bata beton, dilakukan pengujian pada umur 3, 7, dan 28 hari untuk variasi 1 Pc : 8 agregat. Kuat tekan bata beton variasi yang lain diuji pada umur 28 hari. Pengujian sifat fisis meliputi : berat isi, dimensi, dan penyerapan air diuji pada umur 28 hari. Semua benda uji bata beton di curing dengan cara ditutup dengan karung goni basah di pada suhu ruangan sampai dilakukan pengujian sifat mekanisnya.

Bahan yang digunakan dalam penelitian ini adalah bahan perekat jenis portland composite cement (PCC), agregat halus dari jenis pasir alam, limbah tailing penambangan emas UPBE Pongkor, dan debu peleburan bijih besi (debu spons) PT. Krakatau Steel.

\section{Metode Pengujian Bahan}

Sebelum dilakukan pembuatan benda uji beton, dilakukan pengujian terhadap mutu agregat halus, sifat fisik tailing, dan sifat fisik limbah debu. Untuk sifatsifat PC tidak dilakukan pengujian karena digunakan PC yang memenuhi standar SNI. Adapun jenis dan standar pengujian yang digunakan meliputi :

a. Pengujian agregat halus dan tailing meliputi : berat jenis dan penyerapan air sesuai standar pengujian ASTM C - 128 - 93, berat isi asli (ASTM C - 29/C 29 M - 91a ), analisa ayak (ASTM C - 136 - 96a), Kadar air (ASTM C - 566 - 97), Kadar lumpur (ASTM C 117 - 95). b. Pengujian limbah debu meliputi : berat jenis dan penyerapan air, berat isi dan analisa ayak.

Setelah dilakukan pengujian terhadap bahan-bahan penyusun bata beton, prosedur selanjutnya adalah pembuatan benda uji bata beton berlubang dan pengujian kualitasnya.

\section{Pembuatan Bata Beton Berlubang}

Pembuatan bata beton berlubang diawali dengan pencampuran semen, agregat dan air. Proses pencampuran agregat dan semen dilakukan secara kering dengan mesin pengaduk sampai merata kemudian ditambahkan air sampai adukan homogen.

Setelah adukan tercampur secara homogen, kemudian dilakukan pencetakan bata beton dengan alat cetak manual maupun alat semi mekanis. Bata beton yang sudah dicetak dibiarkan ditempat yang teduh dan lembab selama 24 jam. Setelah itu perawatan dapat dilanjutkan dengan cara menutup dengan karung basah, disiram dengan air atau direndam dalam air selama 28 hari untuk mencapai kekuatan yang maksimal. Setelah benda uji berumur 28 hari, dilakukan pengujian terhadap sifat fisik dan mekanisnya sesuai dengan SNI-03-0348-1989.

\section{Pengukuran Dimensi Benda Uji}

Untuk mengetahui ukuran maka diambil 3 buah benda uji yang utuh. Alat ukur yang digunakan Kapiler, alat tersebut dapat mengukur sampai ketelitian 1 $\mathrm{mm}$. Setiap pengukuran panjang, lebar dan tebal bata dilakukan paling sedikit sedikit 3 kali pengukuran, pada tempat - tempat berbeda kemudian dihitung berapa nilai rata - rata dari ke- 3 pengukuran tersebut. Hasil dari 5 buah benda uji, dilaporkan mengenai ukuran rata - rata, ukuran terbesar, ukuran terkecil. 


\section{Pengujian Kuat Tekan}

Pengujian kuat tekan dilakukan dengan membuat benda uji berbentuk kubus, biasanya berukuran $5 \mathrm{~cm} \times 5 \mathrm{~cm} \times 5 \mathrm{~cm}$ yang dipotong dari benda uji aslinya. Setiap benda uji dibuat sedikitnya satu buah kubus. Benda uji yang telah disiapkan, diuji dengan mesin uji tekan yang dapat diatur kecepatan penekanannya. Pengujian kuat tekan dilakukan dengan pembebanan uniaksial dengan kecepatan pembebanan $2-4 \mathrm{~kg} / \mathrm{cm}^{2}$ per detik pada umur 28 hari. Kecepatan penekanan dari mulai pemberian beban sampai benda uji hancur, diatur sehingga tidak kurang dari satu menit dan tidak lebih dari dua menit. Kuat tekan bata beton dihitung dengan rumus:

$\sigma=\frac{\mathrm{P}}{\mathrm{A}} \mathrm{N} / \mathrm{mm}^{2}$ atau $\mathrm{kgf} / \mathrm{cm}^{2}$

Dimana :

$\sigma=$ Kuat tekan beton $\left(\mathrm{N} / \mathrm{mm}^{2}\right)$

$\mathrm{P}=$ beban maksimum dalam Newton

$\mathrm{A}=$ luas bidang tekan benda uji, $\mathrm{mm}^{2}$

Kuat tekan tersebut dilaporkan masing masing untuk setiap benda uji dan juga harga rata - rata dari 5 buah benda uji.

\section{Penyerapan Air}

Untuk pengujian penyerapan air, digunakan 5 buah benda uji dalam keadaan utuh. Alat yang digunakan adalah timbangan yang dapat menimbang teliti hingga $0,5 \%$ dari berat contoh dan oven yang dapat mencapai suhu kurang lebih $105^{\circ} \mathrm{C}$. Benda uji dalam keadaan seutuhnya di rendam dalam keadaan bersih dalam suhu ruangan selama 24 jam. Kemudian benda uji diangkat dari air, dan air sisanya dibiarkan meniris kurang lebih selama 1 menit, lalu benda uji coba diseka/ dilap permukaannya dengan kain basah, untak menyeka kelebihan air yang masih tertinggal, benda uji kemudian di timbang ( A ). Setelah itu benda uji dikeringkan dalam oven dengan suhu $\pm 105^{\circ} \mathrm{C}$, kemudian timbang (B) sampai beratnya tetap pada 2 kali penimbangan tidak berselisih dari $0,2 \%$ dari penimbangan yang pertama. Selisih penimbangan (A) dan (B) adalah jumlah penyerapan air, dan harus dihitung berdasarkan persen berat. Penyerapan air bata beton dihitung dengan rumus:

$P A=\frac{\mathrm{A}-\mathrm{B}}{\mathrm{B}} \times 100 \%$, dimana :

$\mathrm{A}$ = Berat benda uji setelah direndam sampai jenuh (Kg)

$\mathrm{B}=$ Berat benda uji setelah dioven $(\mathrm{Kg})$

PA = Penyerapan Air (\%)

\section{Metode Analisis Data}

Data yang diperoleh dari hasil pengujian sifat fisik dan mekanis bata beton dianalisis dengan cara mencari rata-rata pada masing-masing benda uji yang dikelompokkan sesuai variasinya. Hasil analisis data, berupa sifat-sifat bata beton dibandingkan dengan persyaratan pada SNI-03-0348-1989.

\section{HASIL dan PEMBAHASAN}

\section{Sifat-Sifat Bahan Penyusun Bata Beton}

Sifat-sifat bahan penyusun bata beton berlubang disajikan pada Tabel 4. Dari Tabel 4, terlihat bahwa bahan-bahan yang digunakan untuk membuat bata beton berlubang memenuhi standar.

Tabel 4. Sifat-Sifat Bahan Penyusun Bata Beton

\begin{tabular}{lcc}
\hline \multirow{2}{*}{ Sifat-Sifat Bahan } & \multicolumn{2}{c}{ Jenis Bahan } \\
\cline { 2 - 3 } & Agregat Halus & Tailing \\
\hline Berat Jenis & 2,16 & 2,62 \\
Berat Jenis (SSD) & 2,39 & - \\
Berat Jenis Semu & 2,60 & - \\
Berat Isi Lepas (kg/m3) & 1243,65 & 1187,67 \\
Voids (\%) & 42,23 & 54,72 \\
Berat Isi Padat (kg/m3) & 1370,69 & 1377,22 \\
Voids (\%) & 36,33 & 47,5 \\
Penyerapan Air (\%) & 10,76 & 7,14 \\
Kadar Air (\%) & 9,81 & 1,40 \\
FM (\%) & 3,95 & 7,21 \\
Kadar Lumpur (\%) & 4,58 & 3,38 \\
\hline
\end{tabular}




\section{Berat Jenis Pasir}

Berat jenis pasir akan mempengaruhi kekuatan bata beton. Pasir dengan berat jenis tinggi dapat meningkatkan kuat tekannya. Pasir yang digunakan dalam penelitian ini memiliki berat jenis 2,60. Dilihat dari berat jenisnya, pasir ini memenuhi syarat sebagai agregat normal, yaitu 2,50 - 2,70. Limbah tailing mempunyai berat jenis 2,62. Nilai berat jenis ini lebih tinggi dibandingkan dengan berat jenis pasir.

\section{Berat Isi Lepas Pasir}

Berat isi pasir berfungsi untuk menghitung kebutuhan bahan yang akan digunakan untuk membuat adukan. Berat isi pasir yang digunakan dalam penelitian ini adalah 1243,65 $\mathrm{kg} / \mathrm{m}^{3}$, dimana nilai ini memenuhi persyaratan ASTM C 331 yaitu minimum 1120 $\mathrm{kg} / \mathrm{m}^{3}$ (Anonim, 1994).

\section{Kadar Air dan Penyerapan Air}

Kadar air menunjukkan kandungan air yang ada di dalam pasir, sedangkan penyerapan air adalah kemampuan pasir dalam menyerap air sampai kondisi jenuh. Jika nilai kadar air pasir nilainya lebih kecil dari penyerapannya, maka pasir dalam kondisi kering. Sebaliknya jika kadar air pasir lebih tinggi dibandingkan penyerapan airnya, maka pasir dalam kondisi basah. Kadar air dan penyerapan air pasir berpengaruh terhadap kebutuhan air dalam membuat adukan bata beton yang workable. Hasil uji laboratorium, pasir dan tailing yang digunakan dalam penelitian ini kondisinya kering.

\section{Kuat Tekan Bata Beton Berlubang}

Benda uji berupa bata beton berlubang ukuran $34 \mathrm{~cm}$ x $15 \mathrm{~cm}$ x 8,5 cm. Tailing digunakan sebagai agregat pengganti pasir. Adapun variasi penggantian tailing adalah : $0 \%$ tailing, $25 \%$ tailing, $50 \%$ tailing, dan $75 \%$ tailing. Pada komposisi ini dicoba menggunakan agregat $100 \%$ tailing, namun mengalami kesulitan pada saat pembuatan benda uji, yaitu benda uji sangat rapuh dan mudah hancur. Untuk selanjutnya, benda uji dibuat hanya sampai $75 \%$ tailing sebagai agregat yang menggantikan pasir.

Pembuatan benda uji dilakukan menggunakan mesin semi mekanis, dimana pemadatannya masih manual menggunakan tenaga manusia.Penggunaan tailing pada bata beton dapat meningkatkan kemudahan pada saat pencetakan benda uji. Hal ini terlihat pada saat pencetakan, bata beton yang menggunakan tailing sampai dengan 50\% proses pencetakannya lebih mudah. Namun bata beton yang menggunakan $75 \%$ tailing sudah sulit pencetakannya. Bahkan, pada kadar tailing $100 \%$ benda uji hancur pada saat dikeluarkan dari cetakan. Hasil pengujian kuat tekan rata-rata bata beton disajikan pada Tabel 5 dan Gambar 1.

Tabel 5. Kuat Tekan Rata-Rata Bata Beton Berlubang

\begin{tabular}{ccccc}
\hline \multirow{2}{*}{$\begin{array}{c}\text { Prosentase } \\
\text { Tailing }\end{array}$} & \multicolumn{4}{c}{ Kunat Tekan Rata-Rata Bata Beton (Kg/cm2) } \\
\cline { 2 - 5 } & $\begin{array}{c}\text { Umuri } \\
\text { hari }\end{array}$ & $\begin{array}{c}\text { Umur 14 } \\
\text { hari }\end{array}$ & $\begin{array}{c}\text { Umur 28 } \\
\text { hari }\end{array}$ \\
\hline $0 \%$ & 37,48 & 41,33 & 60,63 & 75,48 \\
$25 \%$ & 23,31 & 27,36 & 32,61 & 41,51 \\
$50 \%$ & 11,05 & 17,55 & 24,65 & 27,43 \\
$75 \%$ & 9,16 & 12,63 & 18,64 & 21,41 \\
\hline
\end{tabular}

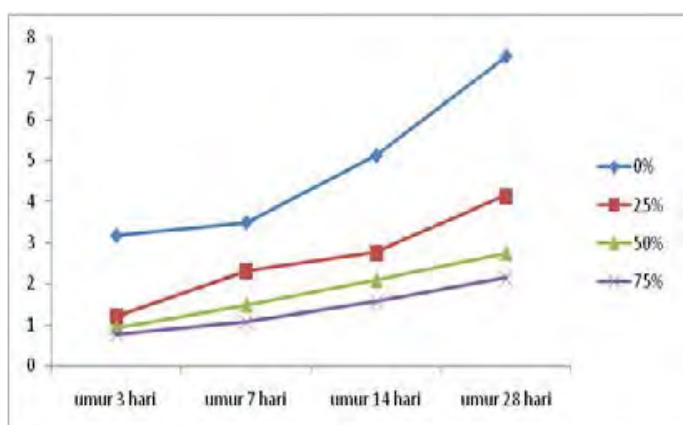

Gambar 1. Perkembangan Kuat Tekan Bata Beton Berlubang 
Kuat tekan bata beton merupakan kemampuan bata di dalam memikul beban yang bekerja pada dinding. Kuat tekan bata beton sangat dipengaruhi oleh mutu agregat, mutu perekat dan komposisi adukannya.

Dari Tabel 5 dan Gambar 1 terlihat bahwa bata beton berlubang tanpa tailing mempunyai kuat tekan tertinggi, yaitu sebesar 75,48 kg/ $\mathrm{cm}^{2}$. Penggunaan tailing sebagai pengganti pasir menurunkan kuat tekan bata beton. Kuat tekan bata beton menurun seiring dengan kenaikan jumlah tailing yang menggantikan pasir. Namun demikian, tailing yang digunakan sebagai pengganti pasir sampai dengan $75 \%$ dapat menghasilkan bata beton dengan kuat tekan yang memenuhi standar SNI.

Kuat tekan bata beton berlubang dengan kadar tailing 25 \% menggantikan pasir, memenuhi standar SNI 03-0349-1989 mutu III yang mensyaratkan kuat tekan minimum sebesar $35 \mathrm{Kg} / \mathrm{cm}^{2}$. Bata beton berlubang mutu III dapat digunakan sebagai dinding pengisi.

Pada adukan yang menggunakan tailing sebagai pengganti pasir sebesar 50\% dan $75 \%$ menghasilkan kuat tekan $27,43 \mathrm{~kg} / \mathrm{cm}^{2}$ dan $21,41 \mathrm{~kg} / \mathrm{cm}^{2}$ memenuhi standar SNI untuk mutu bata IV yang mensyaratkan kuat tekan minimum sebesar $20 \mathrm{~kg} / \mathrm{cm}^{2}$. Bata beton berlubang tipe ini dapat digunakan sebagai dinding penyekat.

\section{Berat Isi Bata Beton Berlubang}

Nilai berat isi bata beton berlubang dengan tailing sebagai pengganti pasir disajikan pada Tabel 6 dan Gambar 2.

Tabel 6. Kuat Tekan Rata-Rata Bata Beton Berlubang

\begin{tabular}{cc}
\hline Prosentase Tailing & $\begin{array}{c}\text { Berat Isi Rata- } \\
\text { Rata (Kg/m3) }\end{array}$ \\
\hline $0 \%$ & 2017,30
\end{tabular}

\section{Lanjutan Tabel 6}

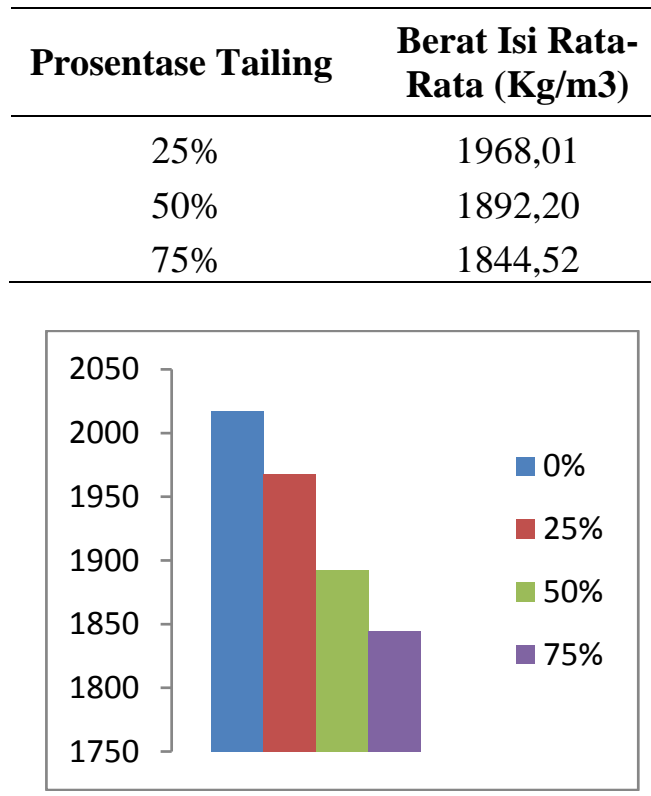

Gambar 2. Berat Isi Bata Beton Berlubang

Berat isi bata beton berlubang merupakan nilai yang meyatakan perbandingan antara berat dan volume bata. Berat isi akan mempengaruhi berat sendiri dinding. Dari Tabel 6 dan Gambar 2 terlihat bahwa bata beton berlubang yang menggunakan tailing sebagai pengganti pasir mempunyai berat isi lebih kecil dibandingkan bata beton tanpa tailing. Semakin besar jumlah tailing yang menggantikan pasir, berat isi bata beton berlubang semakin menurun. Ini berarti dengan menggunakan tailing sebagai bahan pengisi, berat bata beton berlubang menjadi lebih ringan. Kondisi ini disebabkan karena tailing memiliki berat isi lebih rendah dibandingkan dengan berat isi pasir. Bata beton yang mempunyai berat isi lebih ringan akan lebih menguntungkan, karena dapat memperkecil beban yang berasal dari berat dinding.

\section{Dimensi Bata Beton Berlubang}

Nilai berat isi bata beton berlubang dengan tailing sebagai pengganti pasir disajikan pada Tabel 7 sampai Tabel 10. 
Tabel 7. Dimensi Bata Beton Berlubang 0\% Tailing

\begin{tabular}{ccccc}
\hline Sampel & $\begin{array}{c}\text { Panjang } \\
(\mathrm{cm})\end{array}$ & $\begin{array}{c}\text { Lebar } \\
(\mathrm{cm})\end{array}$ & $\begin{array}{c}\text { Tebal } \\
(\mathrm{cm})\end{array}$ & $\begin{array}{c}\text { Volume } \\
(\mathrm{cm} 3)\end{array}$ \\
\hline 1 & 34,8 & 15 & 8,35 & 4358,7 \\
\hline 2 & 34,75 & 15 & 8,30 & 4326,38 \\
\hline 3 & 34,8 & 15 & 8,35 & 4358,7 \\
\hline $\begin{array}{c}\text { Rata- } \\
\text { rata }\end{array}$ & 34,78 & 15 & 8,33 & $\begin{array}{c}4347,92 \\
5\end{array}$ \\
\hline
\end{tabular}

Tabel 8. Dimensi Bata Beton Berlubang 25\% Tailing

\begin{tabular}{ccccc}
\hline Sampel & $\begin{array}{c}\text { Panjang } \\
(\mathrm{cm})\end{array}$ & $\begin{array}{c}\text { Lebar } \\
(\mathrm{cm})\end{array}$ & $\begin{array}{c}\text { Tebal } \\
(\mathrm{cm})\end{array}$ & $\begin{array}{c}\text { Volume } \\
(\mathrm{cm} 3)\end{array}$ \\
\hline 1 & 34,6 & 14,96 & 8,35 & 4322,09 \\
\hline 2 & 34,65 & 15,0 & 8,35 & 4229,91 \\
\hline 3 & 34,65 & 14,98 & 8,30 & 4308,17 \\
\hline $\begin{array}{c}\text { Rata- } \\
\text { rata }\end{array}$ & 35,3 & 14,98 & 8,32 & $\begin{array}{c}4323,39 \\
31\end{array}$ \\
\hline
\end{tabular}

Tabel 9. Dimensi Bata Beton Berlubang 50\% Tailing

\begin{tabular}{ccccc}
\hline Sampel & $\begin{array}{c}\text { Panjang } \\
(\mathrm{cm})\end{array}$ & $\begin{array}{c}\text { Lebar } \\
(\mathrm{cm})\end{array}$ & $\begin{array}{c}\text { Tebal } \\
(\mathrm{cm})\end{array}$ & $\begin{array}{c}\text { Volume } \\
(\mathrm{cm} 3)\end{array}$ \\
\hline 1 & 35,0 & 14,98 & 8,25 & 4325,48 \\
\hline 2 & 35,0 & 14,96 & 8,20 & 4293,52 \\
\hline 3 & 34,95 & 14,96 & 8,25 & 4313,53 \\
\hline $\begin{array}{c}\text { Rata- } \\
\text { rata }\end{array}$ & 34,98 & 14,97 & 8,23 & 4310,84 \\
\hline
\end{tabular}

Tabel 10. Dimensi Bata Beton Berlubang 75\% Tailing

\begin{tabular}{ccccc}
\hline Sampel & $\begin{array}{c}\text { Panjang } \\
(\mathrm{cm})\end{array}$ & $\begin{array}{c}\text { Lebar } \\
(\mathrm{cm})\end{array}$ & $\begin{array}{c}\text { Tebal } \\
(\mathrm{cm})\end{array}$ & $\begin{array}{c}\text { Volume } \\
(\mathrm{cm} 3)\end{array}$ \\
\hline 1 & 34,8 & 14,9 & 8,20 & 4251,86 \\
\hline 2 & 34,8 & 14,92 & 8,20 & 4257,57 \\
\hline 3 & 34,82 & 14,95 & 8,25 & 4294,61 \\
\hline $\begin{array}{c}\text { Rata- } \\
\text { rata }\end{array}$ & 34,80 & 14,92 & 8,225 & $\begin{array}{c}4268,01 \\
6\end{array}$ \\
\hline
\end{tabular}

Dari data dimensi bata beton berlubang terlihat, bahwa penggunaan tailing menurunkan volume bata beton tersebut. Hal ini berarti, penggunaan tailing yang semakin banyak menyebabkan penyusutan yang lebih besar pada beton berlubang.

\section{Penyerapan Air Bata Beton Berlubang}

Nilai penyerapan air bata beton berlubang dengan tailing sebagai pengganti pasir disajikan pada Tabel 11.

Tabel 11. Penyerapan Air Bata Beton Berlubang

\begin{tabular}{cc}
\hline $\begin{array}{c}\text { Prosentase } \\
\text { Tailing }\end{array}$ & $\begin{array}{c}\text { Penyerapan Air Rata- } \\
\text { Rata (\%) }\end{array}$ \\
\hline $0 \%$ & $7,57 \%$ \\
$25 \%$ & $9,00 \%$ \\
$50 \%$ & $11,94 \%$ \\
$75 \%$ & $17,97 \%$ \\
\hline
\end{tabular}

Dari Tabel 11 terlihat, bahwa semakin banyak jumlah tailing yang menggantikan pasir pada bata beton berlubang, maka penyerapan airnya semakin tinggi. Hal ini terjadi karena butiran tailing cenderung halus, dimana sifat agregat yang mempunyai jumlah butiran halus lebih banyak maka luas permukaan agregat yang harus dilumasi air juga lebih besar. Hal ini akan berakibat pada penyerapan air bata beton berlubang. Dilihat dari nilai penyerapan airnya, semua variasi bata beton berlubang memenuhi syarat SNI yang mensyaratkan penyerapan air bata beton berlubang maksimum sebesar 35 $\%$ untuk mutu 1, dan $25 \%$ untuk mutu 2.

\section{KESIMPULAN}

Dari hasil analisa dan pembahasan di atas dapat disimpulkan bahwa :

1. Penggunaan tailing sebagai pengganti agregat pada bata beton berlubang ternyata menurunkan kuat tekan bata beton tersebut.

2. Tailing dapat digunakan sebagai pengganti agregat sampai dengan 75 $\%$, dimana pada komposisi tersebut menghasilkan bata beton berlubang yang masih memenuhi standar SNI 
untuk bata beton kelas IV yang dapat digunakan sebagai dinding penyekat non struktural.

3. Semakin tinggi kadar tailing yang menggantikan pasir, penyerapan air pada bata beton berlubang juga semakin tinggi.

4. Berat Isi bata beton berlubang yang menggunakan tailing semakin banyak, menunjukkan berat isinya menurun.

\section{UCAPAN TERIMAKASIH}

Ucapan terima kasih disampaikan kepada Dirjen Dikti yang telah memberikan bantuan dana dalam melaksanakan penelitian Hibah Bersaing Tahun anggaran 2013.

\section{DAFTAR PUSTAKA}

[1] Anonim. 2002. ASTM Annual Book of ASTM Standards Section 4 Volume 04.02. ASTM 100 West Conshohocken, PA.

[2] Anonim. 1989. SNI-03-0348 tentang Mutu dan Cara Uji Bata beton berlubang. Jakarta: Badan Standarisasi Nasional.

[3] Husin AA dan Setiadji R. 2008. Pengaruh Penambahan Foam Agent Terhadap Kualitas Bata Beton. Jurnal Permukiman Vol. 3 Nomor 3. Bandung: Pusat Litbang Permukiman.

http://puskim.pu.go.id. (Akses tanggal 20 Februari 2012).

[4] Laksono, DW. 2009. Pengaruh Penggantian Sebagian Agregat Pasir dengan Agregat Dari Limbah Plastik Dalam Pembuatan Batako Terhadap Karakteristik dan Kuat Tekan Batako Metode Pressing. Skripsi. Malang: Universitas Muhammadiyah Malang. https://docs.google.com/viewer?a= $\mathrm{v} \& \mathrm{q}=$ cache:07mHH16AC9sJ:skrip si.umm.ac.id/files/disk1/333/jiptum mpp-gdl-s1-2009-davidwahyu-
16619-PENDAHUL-N.

(Akses tanggal 6 Januari 2012).

[5] Prasetyo, R. 2010. Kajian pemanfaatan limbah penambangan emas: studi kasus pemanfaatan tailing di PT. Antam UBPE Pongkor. Abstraksi Tesis. Jakarta: Universitas Indonesia. http://lontar.ui.ac.id/opac/themes/li bri2/detail.jsp?id=117254\&lokasi=l okal. (Akses tanggal 16 Januari 2012).

[6] Saing, Z. 2008. Sifat Pemanfaatan Tailing Sebagai Alternatif Perkerasan Jalan. Jurnal Teknik Dintek Vol. 1 Nomor 2 hal. 53-61. Ternate: Universitas Muhammadiyah Maluku Utara. http://etd.ugm.ac.id/index.php?mod =penelitian_detail\&sub=Penelitian Detail\&act=view\&typ=html\&buku _id=50995\&obyek_id=4. (Akses tanggal 6 Januari 2012).

[7] Sugiarto, A. 2011. Komposisi Campuran Optimum Bata Beton Berlubang Dengan Limbah Batubara Dari Industri Tekstil. Jurnal Permukiman Vol. 6 Nomor 1 hal. 47-52. Bandung: Pusat Litbang Permukiman.

[8] Suhardjo KA dan Basuki A. 2009. Pemanfaatan Limbah Perlit Sebagai Material Bata Beton Ringan. Jurnal Riset Industri Vol. III Nomor 2 hal. 139-144. Bandung: Balai Besar Bahan dan Barang Teknik DEPPERIN.

http://bpkimi.kemenperin.go.id. (Akses tanggal 6 Januari 2012).

[9] Syah RD dan Saputra PD. 2011. Pemanfaatan Limbah Beracun Penambangan Emas (Tailing) Sebagai Agregat Halus Pada Beton Di Lingkungan Laut (Beton Tailing 4sea). Tugas Akhir. Jakarta: Politeknik Negeri Jakarta.

[10]Taufik A dan Setiadji R. 2008. Pengaruh Penambahan Bahan Drilling Cutting Sebagai Bahan Baku Dalam Pembuatan Bata Beton 
Berlobang. Jurnal Permukiman Vol. 3 Nomor 3 hal. 139-144. Bandung: Pusat Litbang Permukiman.

[11]Widodo, dkk. 2010. Pemanfaatan Tailing Pengolahan Bijih Emas Cara Amalgamasi Untuk Bata Cetak. Laporan Akhir Program Insentif Peneliti dan Perekayasa LIPI. Sukabumi: UPT Loka UI Teknik Penambangan Jampang Kulon LIPI. http://km.ristek.go.id/assets.files/LI

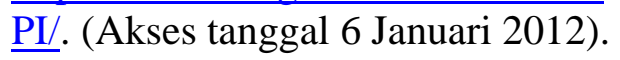


Amalia dan Agus Murdiyoto, Kualitas Bata Beton... 